\title{
TECHNOLOGY TRANSFER IN BUZZ MARKETING
}

\section{TRANSFERÊNCIA DE TECNOLOGIA NO MARKETING DE BURBURINHO}

\author{
Rodrigo Vinícius Sartori ${ }^{1}$; Dálcio Roberto dos Reis ${ }^{2}$; João Luiz Kovaleski ${ }^{3}$; Silvia Gaia ${ }^{4}$ \\ ${ }^{1}$ Universidade Tecnológica Federal do Paraná - UTFPR - Ponta Grossa - Brasil \\ sartori@theoracle.com.br \\ ${ }^{2}$ Universidade Tecnológica Federal do Paraná - UTFPR - Ponta Grossa - Brasil \\ dalcio@utfpr.edu.br \\ ${ }^{3}$ Universidade Tecnológica Federal do Paraná - UTFPR - Ponta Grossa - Brasil \\ kovaleski@utfpr.edu.br \\ ${ }^{4}$ Universidade Tecnológica Federal do Paraná - UTFPR - Ponta Grossa - Brasil \\ gaia@utfpr.edu.br
}

\begin{abstract}
Some innovative companies adopt Buzz Marketing strategy for brand valorization and market share growth: they plant ideas and concepts in Digital Social Networks (like Facebook, YouTube and Twitter), and, in a viral effect, users massively transform it in a gigantic campaign. At same time, what was originally planted is added with new ideas and opinions from Market-users, consumers, potential consumers, specialists, competitors and all kind of stakeholders. So, inside Buzz Marketing process arise real opportunities for Technological Innovation - and be capable to manage it requires a new understand about Technology Transfer: its possibilities under Web 2.0.
\end{abstract}

Keywords: technology transfer; buzz marketing; Web 2.0

\section{Introduction}

\subsection{Research Problem}

Technology Transfer is a concept that is usually translated in some different and very wide contexts. Generally, it is associated with the technical matters (skills, knowledge, technologies, methods of manufacturing, samples of manufacturing and facilities) absorbed by an Organization, a Government or even individuals, from other parts considered "state-of-the-art" about that technology.

It is not rare Knowledge Transfer be taken as Technology Transfer, once most elements of this transference is information - and, as result, the capacity of understand this kind of information, adapting it for other organizational situation and, thus, creating new Knowledge - and applying it, 
for further develop and exploit the technology into new products, processes, applications, materials or services.

There are different routes for Technology Transfer implementation. Often, who transmits valuable information does not do it in an intentional mode. It seems to be possible transfer technology, partially or not, "unconsciously": sensible information is propagated for one public, but may be intercepted for others.

It is the case of what happens in Internet, or, more specifically, in Web 2.0 channels: on Digital Social Networks (DSNs), as blogs, YouTube, Facebook and Twitter, shared content is propagated widely, constantly amplified and reshaped by opinions and ideas of their users.

It has been common companies use strategies known as "Buzz Marketing" in these digital medias: an idea, a quest or even a hoax is carefully planted, aiming this huge mass propagation capacity, for objectives like brands valorization and market share growth, at same time reducing costs by not using traditional (and expensive) medias as TV, radio, outdoors, magazines, etc - Buzz Marketing campaigns are virtually zero-cost.

So, is it possible to identify Technology Transfer processes in Buzz Marketing? If presence in DSNs seems to be every day more important for corporative results, how companies should be ready for managing Technological Innovation through these channels? What are opportunities and risks involved? Is it reasonable planning Buzz Marketing campaigns that directly contribute for Technology Transfer propulsion? This paper discuss how Technology Transfer occurs in Buzz Marketing - with companies conscious about it or not.

\subsection{Rationale}

To be able for seizing opportunities for business innovation and technical opportunities detection based on inside information circulating in DSNs seems to be successful strategy within the competitive world. One of the biggest challenges to strategists of all types of business is to create, maintain and extend competitive advantage for survival and expansion in markets. By identifying a source of opportunities for this strategic objective, ignore their potential benefit may compromise the success of the business already in short term: after all, information is available, and if the company does not anticipate enjoying it, certainly in some time, some competitor will do it.

Competitive advantage based on technological innovation makes possible higher profits, since it offers additional value to Clients. In a competitive scenario focused solely on price and quality, the tendency is commoditization of all products and services: each one occupies its range (dictated by the market) in the perceived cost and benefit by consumers. To escape this trap strategy, and considering that are few entrepreneurs with vision enough to do it, it was asked repeatedly: How to innovate? How can be offered something unique, high value-added to the 
consumers? Is there something that new technologies can contribute to renew value to products and services? There are various sources to get those answers, but a structured Technology Transfer process can identify the best ones and allow that organizations of any type mechanisms to absorber it. And with DSNs, there is an extremely low cost alternative. It is not, however, a simple search for information, after all, as a rule, information is abundant - but what is needed is a process of qualifying, stratify and better enjoy the right information. Buzz Marketing throws in DSNs original ideas planned by companies - but what returns, transformed by the Market's voice, can be more precious than original pretensions: it is loaded of sensible information about opportunities, new ideas and even knowledge about alternative technologies that can be used for Technological Innovation Management.

\subsection{Goal}

\section{MAIN OBJECTIVE:}

Assess how Technology Transfer process occurs in Buzz Marketing. SPECIFICS OBJECTIVES:

- Identify Technology Transfer process in Buzz Marketing.

- Evaluate the role of Experts and Communicators for modifying, increasing and moving sensible knowledge in technological issues.

\section{Theoretical Framework}

\subsection{Web 2.0 and Digital Social Networks (DSNs)}

The advent of second generation of Internet - known as Web 2.0 - has brought new paradigm for the relationship between companies and society, including purchase influencers, buyers and consumers. Web 2.0 is understood for moving Internet as a platform, as well as an understanding of the rules for success in this new platform (O'REILLY, 2005). Among others, the most important rule is to develop applications that leverage network effects to become better the more they are used by people, taking advantage of collective intelligence. Actually, the most successful cases that do it provide a "digital tsunami" that involves hundreds of millions of people (TERRA, 2009).

DSNs are the current technological fruit, provided by Web 2.0, structured on the Chaos Theory's basis, specifically nonlinear systems and fractal geometry studies: supposedly, any two people anywhere in the world are connected for a maximum of six degrees of friendship (like "friend of a friend of a friend of a friend of a friend of a friend") or other kind of relationship (like "neighbor of a friend of a neighbor of a friend of a neighbor of a friend"), as well as the great number of combinations, limited to six levels, from "friends", "neighbors" and other relationship 
types (MILGRAM, 1967).

It is noteworthy that Brazil is a world leader in DSN participation. So, companies operating in this country (Brazilian or foreign companies) can use digital reputation (including competitors' digital reputation) as information source for business decision making. DSN as Orkut, for example, created by North American Google, originally targeted for USA users, has strongly increased its number of Brazilian users, with more than half of the accesses in the world (see Table 1).

Table 1 - Top 10 countries in Orkut number of users

\begin{tabular}{l|r}
\hline Country & Participation \\
\hline Brazil & $50,60 \%$ \\
\hline India & $20,44 \%$ \\
\hline USA & $17,78 \%$ \\
\hline Pakistan & $0,86 \%$ \\
\hline Paraguay & $0,44 \%$ \\
\hline UK & $0,40 \%$ \\
\hline Portugal & $0,36 \%$ \\
\hline Afghanistan & $0,35 \%$ \\
\hline Japan & $0,34 \%$ \\
\hline Canada & $0,33 \%$ \\
\hline source: & \\
Orkut Demographics - September 2010 (http://www.orkut.com/MembersAll)
\end{tabular}

Specially for companies that have products and services targeting yung Brazilian public, decision to keep management of DSN channels is almost mandatory, considering that over half of users are in age of 18 to 25 old years (see Table 2).

Table 2 - Orkut Users Age Ranking

\begin{tabular}{l|r}
\hline Age & Participation \\
\hline $18-25$ & $53,48 \%$ \\
\hline $26-30$ & $14,99 \%$ \\
\hline $31-35$ & $6,68 \%$ \\
\hline $36-40$ & $4,15 \%$ \\
\hline $41-50$ & $4,14 \%$ \\
\hline more than 50 & $3,47 \%$ \\
\hline \multicolumn{2}{|c}{ source: } \\
Orkut Demographics - September 2010 (http://www.orkut.com/MembersAll)
\end{tabular}

There are countless DSN services, but the more world-successful one is the North American Facebook, created by Mark Elliot Zuckerberg, when he was a college student at Harvard (now, because of his most famous creation, is one of the youngest billionaires, with some like US\$ 4 billion (2010), according to the Forbes Magazine online edition (FORBES, 2010). Maintainers of DSNs do not make money directly from audience members (it is free), but selling advertising space for companies interested in this virtual field. The fortune of Facebook creator seems to demonstrate clearly this corporate business potential.

So, with lack of information and few communication and feedback channels, consumers 
have historically always been at disadvantage in confrontations with companies. But with Internet, Web 2.0 fundamentally, all that is changed, not only giving them a collective loud voice, but also an important forum to propagate it. With a new set of technologies and online media shapes - from blogs to wikis, YouTube to Twitter - customers are no longer mere passive observers and won a powerful role. In DSN, they have a much greater power to disseminate his opinion in a visible way, comprehensive and efficient. It has never been so true: the boss is the customer - and it can bring both opportunities and threats for business organizations (BLACKSHAW, 2008).

With new innovation platforms - like Innocentive.com, Cambrian House, Mechanical Turk - innovation comes from hundreds of thousands of problem solvers around the world. Some call it crowd sourcing, or even "weapons of mass collaboration'. For companies, these networks offer a cost effective way to leverage research investments. P\&G's Connect and Develop program reduced R\&D investments from $4.8 \%$ of sales to $3.4 \%$ of sales while at the same time doubling the rate of innovation (VAN OPSTAL, 2010).

Self-Statistics released by Facebook, a system with more than 500 million users, leave no doubt about the importance for companies to closely follow the business trajectory, and the brand new opportunities, in Web 2.0. So, they can permanent keep alignment from their respective target markets and also improve business processes (see Table 3).

Table 3 - Facebook's Self-Statistics

\begin{tabular}{|c|c|}
\hline $\begin{array}{l}\text { People on } \\
\text { Facebook }\end{array}$ & $\begin{array}{l}\text { More than } 500 \text { million active users } \\
50 \% \text { of active users log on to Facebook in any given day } \\
\text { Average user has } 130 \text { friends } \\
\text { People spend over } 700 \text { billion minutes per month on Facebook }\end{array}$ \\
\hline $\begin{array}{l}\text { Activity on } \\
\text { Facebook }\end{array}$ & $\begin{array}{l}\text { There are over } 900 \text { million objects that people interact with (pages, groups, events and } \\
\text { community pages) } \\
\text { Average user is connected to } 80 \text { community pages, groups and events } \\
\text { Average user creates } 90 \text { pieces of content each month } \\
\text { More than } 30 \text { billion pieces of content (web links, news stories, blog posts, notes, photo } \\
\text { albums, etc) shared each month. }\end{array}$ \\
\hline Global Reach & $\begin{array}{l}\text { More than } 70 \text { translations available on the site } \\
\text { About } 70 \% \text { of Facebook users are outside the United States } \\
\text { Over } 300,000 \text { users helped translate the site through the translations application }\end{array}$ \\
\hline Platform & $\begin{array}{l}\text { More than one million developers and entrepreneurs from more than } 180 \text { countries } \\
\text { Every month, more than } 70 \% \text { of Facebook users engage with Platform applications } \\
\text { More than } 550,000 \text { active applications currently on Facebook Platform } \\
\text { More than one million websites have integrated with Facebook Platform } \\
\text { More than } 150 \text { million people engage with Facebook on external websites every month } \\
\text { Two-thirds of comScore's U.S. Top } 100 \text { websites and half of comScore's Global Top } \\
100 \text { websites have integrated with Facebook }\end{array}$ \\
\hline Mobile & $\begin{array}{l}\text { There are more than } 200 \text { million active users currently accessing Facebook through their } \\
\text { mobile devices. } \\
\text { People that use Facebook on their mobile devices are twice as active on Facebook than } \\
\text { non-mobile users. } \\
\text { There are more than } 200 \text { mobile operators in } 60 \text { countries working to deploy and } \\
\text { promote Facebook mobile products }\end{array}$ \\
\hline
\end{tabular}

source:

Facebook / Pressroom - November 2010 (http://www.facebook.com/press/info.php?statistics) 
Technology is diffusing at ever-increasing rates. It took 55 years for the automobile to penetrate a quarter of the U.S. market, but only 35 years for the telephone, 22 years for the radio, 16 years for the personal computer, 13 years for the cell phone and 7 years for the Internet, 3 years for the Ipod and 1 year for Facebook. The first text message was sent in 1992. In 2010, the number of daily texts exceeds the population of the planet. Twitter was launched in 2006; by the end of 2009, the "Twitterverse" had 75 million users. That pace and volatility creates competitive risks but also opportunities. It demands markets that are accepting of new technologies and can accommodate technological agility (VAN OPTSAL, 2010).

\subsection{Buzz marketing and viral marketing}

Buzz Marketing or simply buzz is a term used in word-of-mouth marketing - an alternative way to make marketing activies. Basically, the interaction of consumers and users of a product or service serves to amplify the original marketing message. In other words, it is defined as the amplification of initial marketing efforts by third parties through their passive or active influence (THOMAS JR., 2006).

Early-idea generation projects in virtual world Second Life, for example, are partly driven by marketing aspects to generate buzz and to revamp the corporate image (KOHLER, MATZLER, \& FÜLLER, 2009).

Some describe buzz as a form of hype among consumers, a vague but positive association, excitement, or anticipation about a product or service. Positive "buzz" is often a goal of marketing of viral effect, public relations, and of advertising on Web 2.0 media. This term refers both to the execution of the marketing technique, and the resulting goodwill that is created. Examples of products with strong Buzz Marketing upon introduction were Harry Potter, Volkswagen New Beetle, Pokemon, Beanie Babies, and the Blair Witch Project (DYE, 2001).

Viral Marketing or viral advertising refers to marketing techniques that seek to exploit preexisting DSNs to produce exponential increases in brand awareness, through processes similar to the spread of an epidemic. The definition of viral marketing was originally coined to describe the practice of various free email services to add advertising to the messages coming out of its users. What is assumed is that if such notice to access a "capable", that user will be "infected" and resend the email to other susceptible people, "infecting" them too. As long as each infected user sends mail to more than one user could, on average, the results standard in epidemiology imply that the number

of infected users will grow according to a logistic curve, whose initial segment is exponential (THOMAS JR., 2006).

Viral marketing is sometimes used to describe some types of marketing campaigns based on the Internet, including the use of blogs, seemingly amateur web sites, and other forms of 
astroturfing to create the rumor of a new product or service. The term "viral advertising" refers to the idea that people will share content and fun. This technique is often sponsored by a brand that seeks to build knowledge of a product or service. The viral ads often take the form of entertaining video clips, or interactive flash games, images and even text (THOMAS JR., 2006).

It is possible for firms to track the marketing buzz of their products online using buzz monitoring. For some companies, it is important to understand the buzz surrounding a product before committing to the market. Some facts:

- In a 2007 research, nearly half of people who have used the Internet said that they have conducted searches in price of goods or services in the net $(45 \%)$, while only $16 \%$ reported to have finalized purchase through the web. The data shows that the Internet has consolidated itself as a tool for comparing costs and surveying the availability of goods and services, even if the process of finalizing the purchase of the product does not happen through it (PALETTA; VIEIRA JR., 2008);

- According to the Brazilian Chamber of Electronic Commerce (2005), the revenue from ecommerce in Brazil had nominal growth of $400 \%$ in a period of 5 years. Moreover, a survey commissioned by the Board e.net shows that between 2003 and 2004, the value traded by ecommerce, among businesses and Brazilian consumers, represented $4.22 \%$ of total trading done in Brazil (PALETTA; VIEIRA JR., 2008);

- For the first time in history, it happens, in 2010, that e-commerce sales exceeded retail commerce, in Brazil. The estimates indicate that e-commerce should close the year 2010 with a turnover of US\$ 8.4 billion, an increase of 35\% over the previous year (INCORPORATIVA, 2010).

Buzz monitoring is the keeping track of consumer responses to commercial services and products, to establish the marketing buzz surrounding a new or existing offer. Similar to media monitoring, it is becoming increasingly popular as a base for strategic insight development alongside other forms of market research (MEHTA; DOORLEY; HORVATH, 2009).

This monitor process involves the checking and analysis of myriad online sources such as internet forums, blogs, and DSNs. Data can be provided in real time, which means that critical issues can be picked up instantly. It is also comparatively inexpensive compared to other market research tools and can actually guide further product and service developments (DYE, 2001).

Influence is a key question in buzz monitoring - does this particular person and/or this particular piece of content matter and is it influencing others? Hence, the influence of a source is an important buzz monitoring metric that should be benchmarked (MEHTA; DOORLEY; HORVATH, 2009).

Buzz monitoring is implemented by businesses for a variety of reasons, namely to improve efficiency, reaction times and identify future opportunities. Insights gained can help guide marketing and communications, identify positive and negative customer experiences, assess product 
and service demand, tackle crisis management, round off competitor analysis, establish brand equity and predict market share (THOMAS JR., 2006).

To succeed in a campaign, using viral marketing techniques, it is important to understand who the public-target is. Indeed, the primary public are those people forming opinions, people who influence others. The viral marketing techniques are vast, and the concept is broad. But is possible to illustrate at least three of these techniques: E-mail Marketing, Hot site and Videos (SANTOS, 2006).

The first step for email marketing using viral propagation is to find a segment of potential customers. It is not acceptable to send mass e-mail, or send email to all company's customers, because it can be easily rated as spam, and also requires that the customer authorizes the receipt of the notification (opt-in).

A good way to send targeted e-mail is the use of Customer Relationship Management (CRM), a business approach aimed at understanding and influencing customer behavior through meaningful communications to improve their purchases, retention, loyalty and profitability. CRM is an iterative process that transforms information about customers in positive relationship with them. To work with this concept, however, it is necessary reconfiguration of a database in order to obtain rapidly specific data to all company's customers, according to a parameter to reach a primary target.

The e-mail marketing should be elegant, attractive, informative, clean and, above all, should excite the reader. It should not have long and endless texts; enhances the images, focusing on the main objective of the e-mail, remembering that is insufficient customer just read the email: client must voluntary pass the message to all its "beehive of friends".

It is important to emphasize that human beings like to get close to people who are like them. In these relationships, there are significant experience exchanges, since the issues involved in any conversation between friends are precisely what has been read (e-mail, digital communities), seen (hot site, videos), heard (videos) or felt in any way during the day (SANTOS, 2006).

A hot site is a digital environment for disclosure of a specific product. So, the hot site should be focused, cannot be treated as a form of promotion of various products. In fact, it must contain a single product or service, where the main goal is not to divide the customer's attention with other issues. A motivator hot site it is that one that gains attention. Generally, good practices involve try working with the concept that a product is unique and should be treated like it: this is what does the work of virus transmitting.

Nowadays, Internet is essentially dynamic and the action of opening a website and closing it from browser is constant. Therefore, the purpose of viral marketing is to go beyond. More than the client remains with the website opened, he should promotes the address, sending e-mail to advertise 
the site or by mouth to mouth it (SANTOS, 2006).

About video's strategy for viral marketing, it is recommended very interesting and exciting productions. Video should be exciting or funny, engaging, and, if possible, have a history. Message should be passed naturally, it cannot be enforced as if the Client was forced to "swallow" it. Based on this, then, to spread a "video virus" on the Internet is important, first of all, define suspect, prospect and target (SANTOS, 2006).

Suspect are those people that are not part of the focus of viral campaign. They are usually people who know that there is this media (internet / video), but not interested in this exhibition. Therefore, they are not the right public.

Prospect are those social groups closer to company's reality. Sometimes they do not have resources to access videos, they know it exists, they would like to see the video, but are not strongly influenced to do it, often by lack of resources.

The key for this type of marketing is the Target - the target audience. Who directly will make video propagation through the Internet (buzzers). These are people who are part of a small, segmented and important group. Identify the primary target is the main point to start thinking about the video development.

Communicators and experts are two distinct categories of buzzers. Communicators involve people with no additional knowledge to contribute, but with extensive number of "friends" in their DSNs - guarantee of massive audience for their digital movements. Experts are those people characterized for large knowledge (the "specialists"), often with limited followers (THOMAS JR., 2006; DYE 2001). The viral effect of the buzz marketing precisely occurs because of this explosive interaction - some of them talk, some others promote, and the huge mass is involved.

The essence of viral marketing is just the spontaneous release from person to person - so, creative and motivating content is fundamental (SANTOS, 2006).

\subsection{Management 2.0}

It seems that always good practices of Business Management aim to a dual and simultaneous focus: add value where necessary and eliminate costs where possible. The intensive use of Web 2.0 for this proposal provides a new organizational paradigm: "Management 2.0". It should be understood as a framework formed by collaborative environments processes realigned to "Marketing 2.0", "Work 2.0", "Sustainability 2.0" and "Innovation 2.0" (TERRA, 2009). Figure 1 shows its main features. 
Figure 1 - Management 2.0 Model

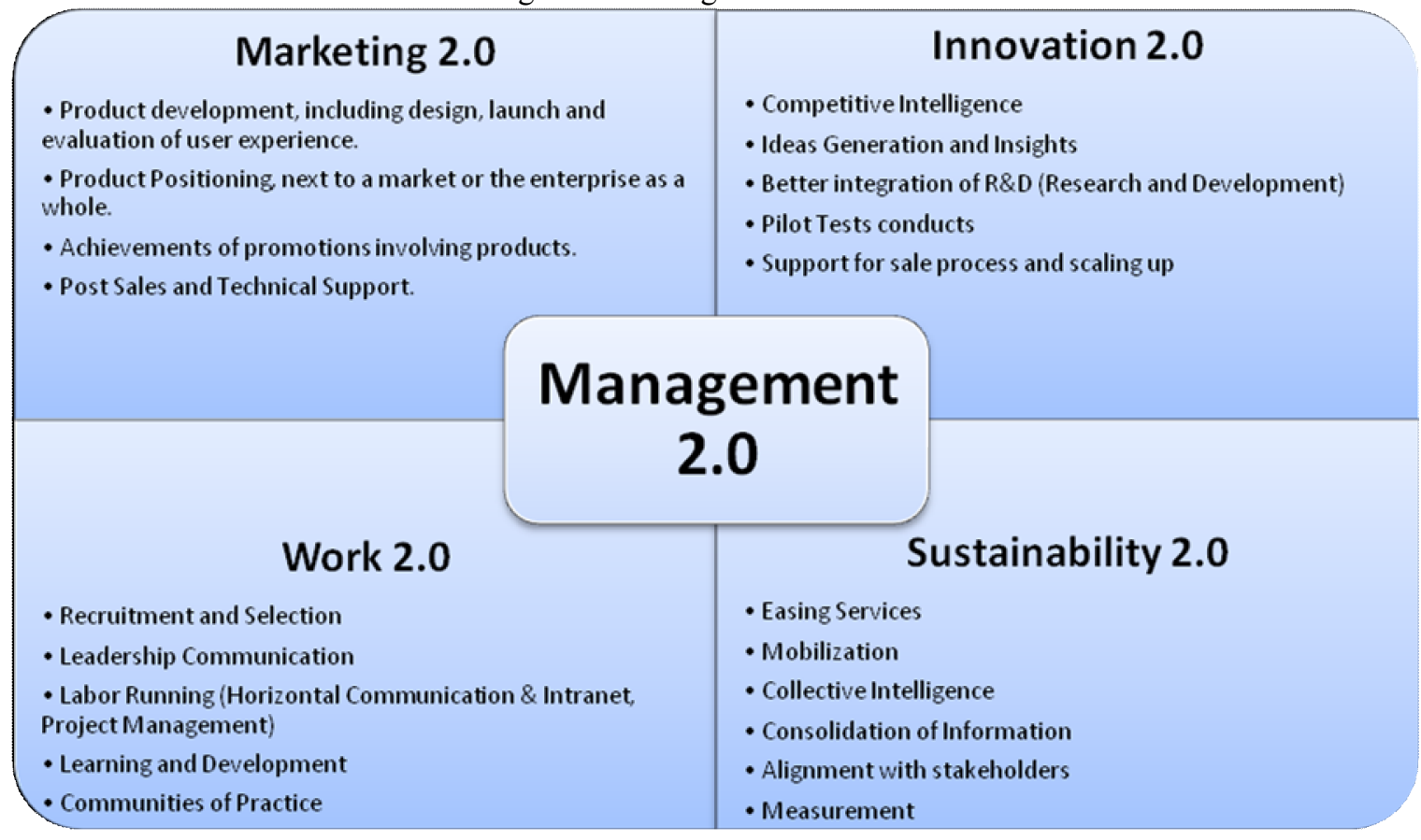

Source: TERRA, 2009

The opportunities for using virtual worlds for real-life innovations are really manifold. However, the arguments can be structured along two key dimensions. The first dimension captures the notion that existing customer integration tools should capitalize on the advances of information and communication technologies. The second dimension relates to the nature of virtual worlds and their native creativity (KOHLER; MATZLER; FÜLLER, 2009).

\subsection{Technology transfer}

Technology acquisition (transfer) is one way to enable an industry to keep in touch with the latest trends of an accelerated technology, and has continued to be a popular strategy for corporate growth (HAGEDOORN; SCHAKENRAAD, 1994).

It is a process of planned, selective, focalized importation of advanced technology which the enterprise has neither domain nor competence, and new application of imported technology which can bring expectant economic benefits to new users (HUNG; TANG, 2008; TIDD; BESSANT; PAVIT, 2005).

In a complete innovation system, it is observed that the industrial base is composed by a set of firms characterized by different sectors, sizes, and ages. These characteristics together with their organizational strategies and technical capabilities determine the type of relationship firms will have with each other (cooperation, complementarity or competition) to get benefits in the market (PEREIRA; PLONSKI, 2009). So, it defines the routes of technology transfer in this scenario.

Technology Transfer maybe is easier to define than to measure, for instance an organization, mainly research institutes, can have a lower number of publications, but of higher quality than 
another one (COCCIA \& ROLFO, 2008).

Science is created in academy. But there is a tendency of cut-off investments, in times of economics crisis. Researches of frontier (whose success is difficult to predict), spontaneous researches, changes of research trails and the search for new connections between scientific fields might become endangered species in science in modern capitalistic system of the globalization Era (COCCIA; ROLFO, 2008). It looks that companies cannot exclusively depend on academics efforts, for technological innovation. Other sources are strictly necessary.

Figure 2 shows a specification of Technology Transfer model from different aspects related to resource commitment (HUNG; TANG, 2008).

Figure 2 - Specification of Technology Transfer model

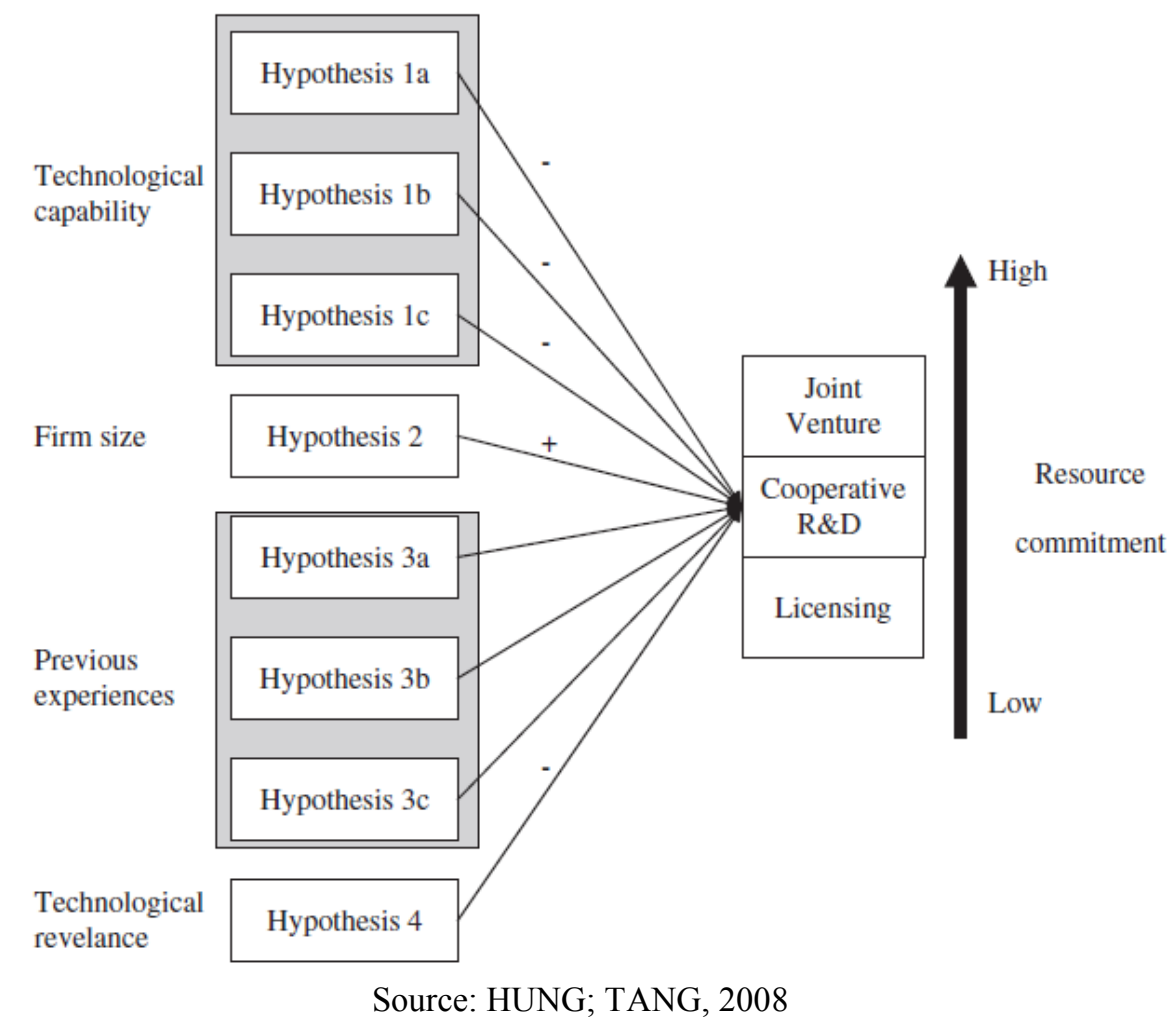

\section{Methodological procedures}

Literature review was used on the topics of Technological Innovation, Web 2.0 / DSNs, Buzz Marketing / Viral Marketing and Technology Transfer, and also professional experience / personal experience of the researcher.

It is a research of predominantly exploratory nature, as this provides more problem familiarity, for making it more explicit or to build hypotheses (GIL, 1996). It was aimed, therefore, the improvement of ideas / insights discovery. The exploratory study is recommended in cases where there is little knowledge about the problem to be studied (CERVO; BERVIAN, 1983), which is applicable to this work subject. 


\section{Results}

A complex net of interactions between all actors involved in Buzz Marketing - involving companies, brands, purchasers, consumers, purchase influencers, specialists, business partners and many others stakeholders - allows to establish the following framework concerning Technology Transfer (see Table 4):

Table 4 - Proposed framework for Technology Transfer in Buzz Marketing

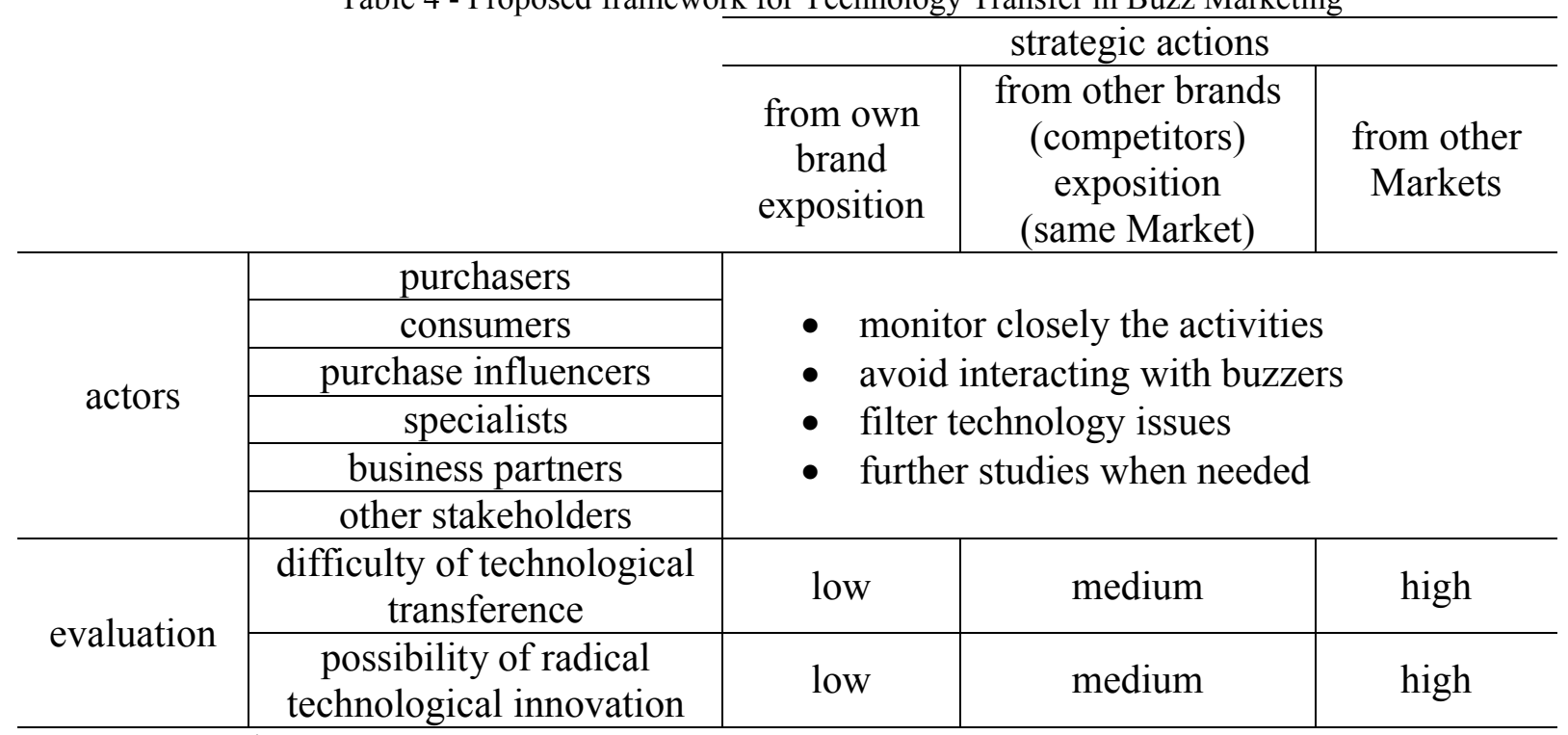

Source: own authory

Since information (and knowledge) generated from Buzz Marketing are freely available in DSNs, it is possible to companies extend their analysis to competitors: also taking actions from other brands exposition in their own Viral Marketing campaigns. It is a legitimate new frontier for Competitive Intelligence process. But, like in conventional Competitive Intelligence process, antispy techniques are dangers to consider: false information can be planted by a company, for buzz effect, just to cheat competitors or making temporary distractions.

In a process of Technology Transfer, digital reputation performance is one of the significant criterions that can be used for choosing new technologies of company's interest. Probably, a lot of opportunities can return from amplified buzz information circulating on digital channels - so, a filter of relevance is asked for easier decision making. Although, different from Reputation Management strategy, in Buzz Marketing a principle to respect is not interact directly with users, avoiding break spontaneity of their new information added to buzz message. In this context, the interest is to tease for new technological information that those users can have.

\subsection{Actors roles}

Purchasers, consumers and purchase influencers are not always the same person, depending on business configuration: so, their interest can be different, and also their contribution for 
technological issues.

It is impossible for a company direct strictly for one specific public its Buzz Marketing campaign: in a first interaction, company choose for whom to send the provocative information. But, because viral effect, each DSN user can freely resend it for an undetermined number of other users (of personal network), and with all kind of different profiles. It is not under control for whom it goes, but it is accessible to identify who are buzzers users - in most of cases, a message sent in DSNs carries together identification of its source. Exception: anonymous posts.

Purchase influencers can be, for example, a doctor, that do not consumes a product (medication), but can recommend it (or not) for patients, depending on a interpretation of technical and functional features. Purchaser can be a mother, and final consumer can be her child. In fact, it is very common that each one of them accesses DSNs, with different interests, so, different types of contribution to make, sharing information with potential to technological transfer.

In general, purchase influencers act as experts, and purchasers - and mainly consumers tend to behave more as communicators, in viral analysis.

Specialists are paid people to give refined technological information. However, when a company pays for it, maybe not all fundamental information could be acquired. Or, in some cases, the knowledge validity could be questioned. For example, how controversial is tobacco industry consider that its products turn less dangerous for consumers, with new technologies adopted in filters and composition, when the scientific research is made by people paid for this industry? Even if really a new component is demonstrably less toxic to certain characteristic, could it have a side effect of, for example, be more addictive? Does all the information, the most positive and most negative, gain the same consideration - the ideal ethics of scientific research? Upton Sinclair Jr. (North American writer) once said: "It is difficult to make a man understand, when his salary depends on his not understanding".

This does not completely invalidate work (paid) of specialists (typical experts of viral process), but it opens a new complementary possibility: confirm real and sincere scientific opinion through Web 2.0 tools, when some experts are identified among the buzzer users. Buzz is not a talk between users and companies: it is a talk between users - in this case, between two or more specialists. This is the best opportunity for technological transfer when they are involved in a viral campaign of Buzz Marketing.

Business partners, as suppliers, class associations, syndicates, etc, can contribute with information that, in technological view, allows evaluating if partnership continues strategic or not. A supplier that proves frightened in digital conversations, fearing technological capacity for following the development requested by corporate clients, should be carefully evaluated. Political issues filtered on DSNs, from class associations and syndicates, can be useful to identify barriers for 
technological innovation. It is a tendency of expert behavior.

Other stakeholders cannot be underestimated in this framework. It is licit to ask what every society element can contribute to better understanding technological routes. Non-profit organizations, in some cases, have people with high academic level, and probably with the most sincere opinion and deep knowledge about technological issues. Once involved in buzz marketing campaigns, these people contribute with valued information about social-political impacts of each technology considered. Also, much more experts than communicators.

\subsection{Strategic action - monitor closely the activities}

It is not possible full control about the effect of a viral marketing campaign, in aspects as number of people affected, number of people that make buzz (reply / amplify information), type of contribution that is done, and, mainly, who will be involved effectively. If information is likely to be misinterpreted, it should not architect it in a buzz marketing campaign.

What occurs is, if is viral, is fast. So, it is necessary monitor closely these activities in DSNs, because it is prudent trying to stop (or at least stop accelerating) a campaign that is unsuitable for the company, or encourage it to continue if the results prove be very interesting.

Buzzers can return to company a large number of contributions - among them, technological possibilities. The problem, then, is that information is publicly available: competitors can use it. So, to react quickly to a detected possibility can make the process of technology transfer happen first for the company, thus, generating competitive advantage.

As in a Competitive Intelligence procedure, priority for a company is its own buzz campaign - but is very useful try to read results from competitor's buzz campaigns too, since that try to protect company from the onslaught of competitor on its own campaign is virtually impossible.

A real innovative action, that is not common between traditional competitors, is try to reach results of buzz marketing from other Markets or segments. It makes possible high valued innovations. For example, what if a rent-a-car business organization was interested in viral campaigns of air companies, what kind of technological possibilities could be identified for innovation in rent-a-car market? Or alcohol industry monitoring buzz marketing from sodas? The rule is: less competitors on a segment, more profits - so, how about creating new segments?

\subsection{Strategic action - avoid interacting with buzzers}

This is the main difference between Reputation Management and Buzz Management. When reputation is the goal, it is very important for a company reaction and interaction with brand buzzers, trying to control the impact on its public image.

But, in a buzz process, the apparently "blind eyes" strategy of a company is what guarantee 
the legitimacy of that content regenerated and propagated in DSNs. When people think that could talk (or write) with no company supervision, they feel free to be honest and straight about a lot of information - but, in this context - the most valuable is technological issues.

Traces of presence in DSNs could, also, prematurely awake reaction from competitors. To be "invisible" between buzzers, therefore, is wise.

\subsection{Strategic action - filter technology issues}

In a buzz campaign, people can virtually talk (or write) about almost everything. It is sure that buzz must be filtered, to reveal significant technological issues.

Howsoever, that does not mean restrict only at technical data. Technology is, fundamentally, an application of a scientific knowledge for industrial purposes. So, for beyond technical data, context information must be collected to real possibilities of technological innovation.

A possible script for this filter could involve:

- Does this buzz contain information about new necessities of consumers?

- Does this buzz contain information about features that are no longer valued by consumers?

- Does this buzz contain information about features already available but that is wished to be increased much more?

- Does this buzz contain information about features already available but that is wished to be reduced much more?

- Does this buzz contain information about new technologies?

- Does this buzz contain information about features of competitors?

- Does this buzz contain information about features of other Markets or segments?

- Does this buzz reveal underserved subgroups within a consumer group?

- Does this buzz reveal irrefutable tendencies?

- Does this buzz criticize political and social-environment impacts of technologies?

- Does this buzz reveal new experts for requested technology?

- Does this buzz contribute to technological forecasting?

- Does this buzz indicate new scientific basis to consider?

\subsection{Strategic action - further studies when needed}

In a conventional Technology Transfer process, information uses to flow in an unique block. Once identified sources, almost everything about that technology is covered. With buzz marketing, relevant knowledge is often divided in a myriad of sources. So, further studies are necessary when technological knowledge of interest is detected. In Figure 3 below, the size of circles represents the 
knowledge availability.

Figure 3 - Difference of Technology Transfer in Buzz Markeging

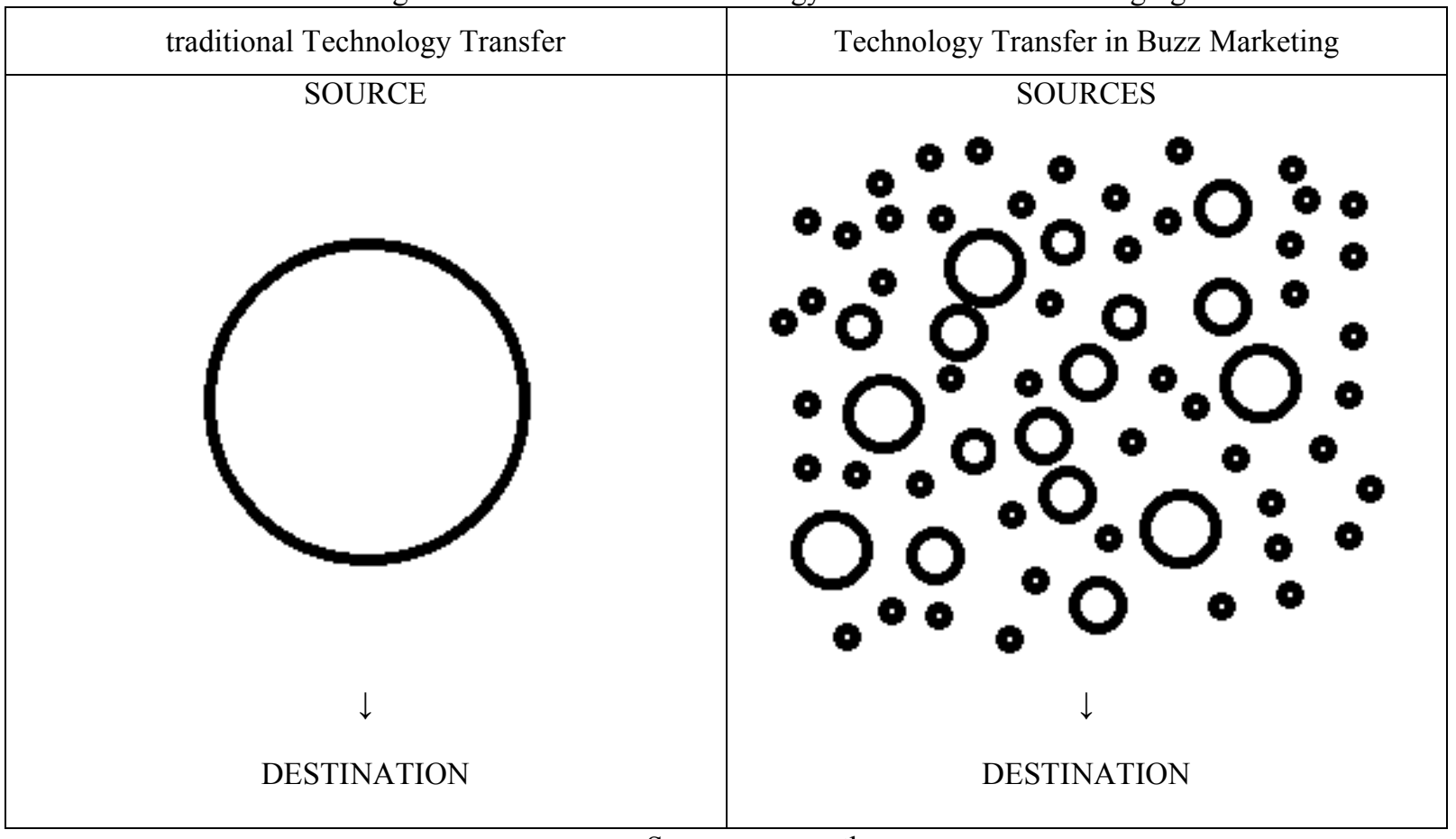

Source: own authory

\section{Concluding Remarks}

Results demonstrate that Technology Transfer seems not be fully developed in a Buzz Marketing campaign. Or, at least, it is not possible to companies an exclusively dependence from viral actions in Web 2.0 to acquire technology.

However, it is not the intent of a buzz campaign this integral responsibility. Buzz strategy will always have, as main goal, Marketing results. In Reputation Management, its role is unquestionable.

But it is not deniable that Buzz Marketing directly contributes to Technology Transfer processes, by increasing the number of opportunities sources to consider. In a traditional Technology Transfer process, there are few sources, with great knowledge to supply. In Buzz Marketing field, number of sources could be virtually infinite, and each source, in expert or communicator roles, has a proportionally smaller knowledge to share. One of these sources, individually, may not interest to the company - but the total knowledge originated from all sources together, perhaps, could be greater than that unique source from traditional Technology Transfer process.

In this context, there is that old reflection: what is more intelligent, depending $100 \%$ of a single source performance, or depending $1 \%$ of 100 distinct sources performance?

Further studies need to better developing structured models of processes of Technology Transfer in Buzz Marketing. A possible solution involves approximation of disciplines of 
Knowledge Management, Technological Innovation Management, Competitive Intelligence, Web 2.0, Digital Marketing and Technological Forecasting. Contribution and sharing are key concepts to draw another paradigm in the relationship among companies, consumers and society.

DSNs have an essential role as business axis nowadays, because it moves the voice of the Market. This is not a fad, this is an irreversible fact. This involves, but is not limited to Technology. And, considering that is historically something still new, there is risk of total ignorance of older companies, or, mainly, companies with older mental models of administration.

After all, the real world creates and shapes the virtual world, however, it must be remembered the information reprocessed returns to the real world, which undoubtedly also suffer their effects - positive or negative. Currently, such a return seems more and more crucial, especially for corporate business.

The reality of the online world has transformed the brand credibility in the most important value for today's businesses. This is a world where success can comes quickly, but failure probably much more rapid. This is a world where "Management 2.0" is just in the begging.

\section{Resumo}

Some innovative companies adopt Buzz Marketing strategy for brand valorization and market share growth: they plant ideas and concepts in Digital Social Networks (like Facebook, YouTube and Twitter), and, in a viral effect, users massively transform it in a gigantic campaign. At same time, what was originally planted is added with new ideas and opinions from Market - users, consumers, potential consumers, specialists, competitors and all kind of stakeholders. So, inside Buzz Marketing process arise real opportunities for Technological Innovation - and be capable to manage it requires a new understand about Technology Transfer: its possibilities under Web 2.0.

Keywords: technology transfer; buzz marketing; Web 2.0.

\section{References}

BLACKSHAW, P. Satisfied customers tell three friends, angry customers tell 3,000: running a business in today's consumer-driven world. Crown Business, 2008.

COCCIA, M., ROLFO, S. Strategic change of public research units in their scientific activity. Technovation $28: \mathrm{p}$. 485-494, 2008.

cross ${ }^{\text {ref }}$

DYE, R. The buzz on buzz. Harvard Business Review, 2001.

CERVO, A. L., BERVIAN, P. A. Metodologia Científica: para uso dos estudantes universitários. $3^{\text {a }}$ Ed. São Paulo: McGraw-Hill do Brasil, 1983.

FORBES Magazine (Online Edition). Lists of World's Billionaires. Available in

$<$ http://billionaires.forbes.com/topic/Mark_Zuckerberg>. Access in September 21, 2010.

GIL, A. C. Como elaborar projetos de pesquisa. São Paulo: Editora Atlas, 1996. 
HAGEDOORN, J., SCHAKENRAAD, J. The effect of strategic technology alliances on company performance. Strategic Management Journal 15: p. 291 - 311, 1994.

cross ${ }^{\text {ref }}$

HUNG S. W., TANG R. H. Factors affecting the choice of technology acquisition mode: an empirical analysis of the electronic firms of japan, korea and taiwan. Technovation 28: p. 551 - 563, 2008.

cross $^{\text {ref }}$

INCORPORATIVA. Comércio eletrônico supera vendas de shopping centers em SP. Available in $<$ http://www.incorporativa.com.br/mostranews.php?id=4779>. Access in November 23, 2010.

KOHLER, T.; MATZLER, K.; FÜLLER, J. Avatar-based innovation: using virtual worlds for real-world innovation. Technovation 29: p. 395-407, 2009.

cross ${ }^{\text {ref }}$

MEHTA, M.; DOORLEY, T.; HORVATH, M. Future signals: how successful growing companies stay on course. Ivey Business Journal. Available in <http:/www.hrpao.org/NR/rdonlyres/559B3665-D4FF-4A34-A83A-

771DAA23D1BE/0/FutureSignals.pdf $>$. Access in November 20, 2010.

MILGRAM, S. The small world problem. Psychology. Today 2, 60-67, 1967.

O'REILLY, T. Design patterns and business models for the next generation of software. 2005. Available in $<$ http://oreilly.com/web2/archive/what-is-web-20.html>. Access in April 25, 2010.

PALETTA, F. C.; VIEIRA JR., N. D. Information technology and communication and best practices in it lifecycle management. Journal of Technology Management \& Innovation: Volume 3, Issue 4, p. 80-94, 2008.

PEREIRA, L., PLONSKI, G. A. Shedding light on technological development in Brazil. Technovation 29: p. 451 464, 2009.

cross ${ }^{\text {ref }}$

SANTOS, S. Marketing viral na web. Available in

<http://imasters.com.br/artigo/5200/webmarketing/marketing_viral_na_web>. 2006. Access in November 20, 2010.

TERRA, J. C. Gestão 2.0: como integrar a colaboração e a participação em massa para o sucesso nos negócios. Rio de Janeiro: Elsevier, 2009.

THOMAS JR., G. M. Building the buzz in the hive mind. Journal of Consumer Behavior, Volume 4, Issue 1: p. $64-$ $72,2004$.

cross ${ }^{\text {ref }}$

TIDD, J.; BESSANT, J.; PAVITT, K. Managing Innovation: integrating technological, market and organizational change. 3. ed., 2005.

VAN OPSTAL, D. Commentary on Gregory Tassey's "Rationales and mechanisms for revitalizing US manufacturing R\&D strategies”. The Journal of Technology Transfer 35: p. 355-359, 2010.

\section{Dados dos autores:}

\section{Nome completo: Rodrigo Vinícius Sartori}

Filiação institucional: UTFPR - Universidade Tecnológica do Paraná

Departamento: PPGEP - Programa de Pós-Graduação em Engenharia da Produção

Função ou cargo ocupado: Mestrando em Engenharia da Produção - Ênfase em Gestão do

Conhecimento e da Inovação

Endereço completo para correspondência (bairro, cidade, estado, país e CEP): Av. Monteiro

Lobato, S/N - Km 04, Jardim Carvalho - Ponta Grossa - PR - Brasil, CEP 84016-210 
Telefones para contato: (41) 8413-0580

e-mail:sartori@theoracle.com.br

Nome completo: Dálcio Roberto dos Reis

Filiação institucional: UTFPR - Universidade Tecnológica do Paraná

Departamento: PPGEP - Programa de Pós-Graduação em Engenharia da Produção

Função ou cargo ocupado: Professor doutor

Endereço completo para correspondência (bairro, cidade, estado, país e CEP): Av. Monteiro

Lobato, S/N - Km 04, Jardim Carvalho - Ponta Grossa - PR - Brasil, CEP 84016-210

Telefones para contato: (42) 3220-4800

e-mail:dalcio@utfpr.edu.br

Nome completo: João Luiz Kovaleski

Filiação institucional: UTFPR - Universidade Tecnológica do Paraná

Departamento: PPGEP - Programa de Pós-Graduação em Engenharia da Produção

Função ou cargo ocupado: Professor doutor

Endereço completo para correspondência (bairro, cidade, estado, país e CEP): Av. Monteiro

Lobato, S/N - Km 04, Jardim Carvalho - Ponta Grossa - PR - Brasil, CEP 84016-210

Telefones para contato: (42) 3220-4800

e-mail:kovaleski@utfpr.edu.br

Nome completo: Silvia Gaia

Filiação institucional: UTFPR - Universidade Tecnológica do Paraná

Departamento: PPGEP - Programa de Pós-Graduação em Engenharia da Produção

Função ou cargo ocupado: Professora doutora

Endereço completo para correspondência (bairro, cidade, estado, país e CEP): Av. Monteiro

Lobato, S/N - Km 04, Jardim Carvalho - Ponta Grossa - PR - Brasil, CEP 84016-210

Telefones para contato: (42) 3220-4800

e-mail:gaia@utfpr.edu.br

Enviado em: 09/02/2011

Aprovado em: 26/06/2011 